\section{Therapeutic benefits of lemongrass and tea tree}

\author{
Nida Tabassum Khan* \\ Department of Biotechnology, Faculty of Life Sciences and Informatics, Balochistan University of \\ Information Technology Engineering and Management Sciences, (BUITEMS), Quetta, Pakistan
}

\section{Abstract}

Lemongrass is a culinary herb with a lemony aroma.it is mostly cultivated in Southeast Asia, Sri Lanka, Indonesia and India. It is conventionally used for relieving anxiety, stress and pain. Because of the presence of limonene and citral, lemongrass extracts exhibits antimicrobial, antidandruff and anti-inflammatory effects. However Tea tree extracts are mostly employed in the treatment of dermal, inflammatory and microbial infections.

\section{Introduction}

Lemongrass is commonly used in Asian cooking because of its lemony aroma and citrus flavor [1]. Besides this plan is also employed in aromatherapy to reduce stress, pain etc and elevates the mood [2].

\section{Bioactive constituents}

Lemongrass is an enriched source of fiber, carbohydrates, Vitamin A, B and C that strengthens body immune system, repairs tissue damage and promotes cell division respectively $[3,4]$, magnesium that is required for protein synthesis, function and fertility [6], phosphorus for DNA/RNA and cell membrane synthesis [7], zinc required for wound healing, normal growth and development [8].

\section{Health benefits of lemongrass}

Lemongrass offers numerous health benefits which are as follows:

- Antioxidant properties: Lemongrass possess numerous antioxidants such as isoorientin, chlorogenic acid and swertiajaponin which aids in hunting free radicals that may cause disease [9]. Antimicrobial properties: Lemongrass extracts exhibits antimicrobial potency against Streptococcus mutans and thus used to prevent tooth decay [10].

- Antiinflammatory properties: Antiinflammatory property of Lemongrass is attributed to the presence of compounds citral and geranial which helps in preventing the release of certain inflammation-causing markers in our body [11]. glycolysis and muscle activity [5], selenium for cognitive

\section{More Information}

*Address for Correspondence: Nida Tabassum Khan, Department of Biotechnology, Faculty of Life Sciences and Informatics, Balochistan University of Information Technology Engineering and Management Sciences, (BUITEMS), Quetta, Pakistan, Tel: 03368164903;

Email: nidatabassumkhan@yahoo.com

Submitted: 18 May 2020

Approved: 28 May 2020

Published: 29 May 2020 benefits of lemongrass and tea tree. Ann Civil Environ Eng. 2020; 4: 027-029.

DOI: 10.29328/journal.acee.1001022

Copyright: @ 2020 Khan NT. This is an open access article distributed under the Creative Commons Attribution License, which permits unrestricted use, distribution, and reproduction in any medium, provided the original work is properly cited.

Keywords: Chlorogenic acid; Citral; Geraniol; Erythropoiesis; Eczema; Anemia; Contact dermatitis

D) Check for updates

(8) OPEn Access
How to cite this article: Khan NT. Therapeutic

- Anticancer properties: Presence of bioactive citral in Lemongrass helps fight cancer either by apoptosis or boosting immune system [12].

- Promotes healthy digestion: Lemongrass tea is reported to treat stomach discomforts, indigestion and gastric ulcers by protecting stomach lining [13].

- Reduce high cholesterol: Lemongrass extract assisted in lowering high cholesterol levels in humans [14]. Treats obesity: Lemongrass tea helps in losing excess of weight in obese patients [15].

- Skin treatment: Research indicated that lemongrass essential oil is used as a therapeutic agent for the treatment of inflammatory skin conditions [16].

- Repellent: Lemongrass extract is used in the preparation of insect repellents due to the presence of compounds citral and geraniol [17].

- Controls dandruff: Lemongrass oil is used in hair tonics to reduce dandruff through its antimicrobial and anti-inflammatory properties [18]. It also inhibits the growth of fungi $M$. furfur that is associated with dandruff [19].

- Prevents anemia: Research reported that since 
Lemongrass is an enriched source of iron and other minerals, it promotes erythropoiesis to prevent the symptoms of anemia [20].

- Treats oral issues: Lemongrass extracts help fight inflammation of gums and cavities [21].

\section{Side effects of lemongrass}

Lemongrass is usually considered safe to use in cooking however if consumed in excess may exhibit potential side effects such as tiredness, dry mouth, dizziness, increased appetite, frequent urination, allergic reactions such as itching and rash [22,23]. Moreover avoid its use during pregnancy since it starts menstrual flow [24].

Tea tree is native to Queensland and New South Wales, Australia and is botanically known as Melaleuca alternifolia [25]. Tea tree oil has been used as a conventional medicine by Aborigines and Australians for treating common cold and cough [26]. Tea tree extract contains terpinen-4-ol, which is an antimicrobial agent and enhances white blood cells activity against foreign pathogens [27].

\section{Health benefits of tea tree extracts}

Tea tree offers numerous health benefits which are as follows:

Antiseptic: Tea tree extract is used in the preparation of hand sanitizer and cleansers since it is effective against infection causing bacteria and viruses including $E$. coli, $S$. pneumoniae and $H$. influenzae [28].

Repellent: Tea tree extract has the property to repel insects such as mosquitoes, bees, wasps, ants etc making it suitable to be used as a repellent [29].

Antifungal/Antibacterial: Tea tree oil is used in the treatment of fungal nail infection (onychomycosis), and bacterial acne [30]. In addition it also aids in relieving inflamed skin such as contact dermatitis [31].

Treats dermal infections: Tea tree oil helps in the treatment of dry skin by reducing itching, eczema, combat oily skin, acne lesions and contact dermatitis [32].

Anti-inflammatory: Tea tree extractreduces inflammation due to high content of terpinen-4-ol, it soothe and relieve painful irritated skin [33].

Wound treatment: The antibacterial activity of tea tree extract makes it an effective wound healer [34].

Hair/scalp treatment: Tea tree extract is reported to be antidandruff therefore is suitable in treating hair dandruff and itchy scalp [35].

\section{Conclusion}

Thus Tea tree and Lemongrass both are widely used for its numerous health benefits and in treating several ailments.

\section{References}

1. Ranade SS, Thiagarajan P. Lemon Grass. Int J Pharmaceu Sci Rev Res. 2015; 35: 162-67.

2. Buckle J. Clinical aromatherapy and touch: complementary therapies for nursing practice. Critical care nurse. 1998; 18: 54. PubMed: https://www.ncbi.nlm.nih.gov/pubmed/9934050

3. Nambiar VS, Matela H. Potential functions of lemon grass (Cymbopogon citratus) in health and disease. Int J Pharmaceut Biol Arc. 2012; 3 : 1035-1043.

4. Abbas SM, El-Saeid HM. Effects of some growth regulators on oil yield, growth and hormonal content of lemon grass (Cymbopogon citrates). Botanica Serbica 2012; 36: 97-101.

5. Prasad A, Kumar D, Singh DV. Effect of soil sodicity on the growth and cation composition of palmarosa and lemongrass. Journal of herbs, spices \& medicinal plants. 1998; 5: 51-60.

6. Alsogayer AA. Organic Selenium, Probiotics, and Prebiotics Effects on Growth, Blood Biochemistry, and Carcass Traits of Growing Rabbits During Summer and Winter Seasons. Springer. 2018.

7. Singh M, Nagar N, Upadhyay Ak, Chandel BS. Effect of potassium and zinc on yield, mineral composition and quality of lemon grass under saline condition. Annals of Plantand Soil Research. 2012; 14: 101-104.

8. Ranjah MA. Lemongrass: a useful ingredient for functional foods. International Journal of Food and Allied Sciences. 2019; 4: 11-19.

9. Balakrishnan B, Paramasivam S, Arulkumar A. Evaluation of the lemongrass plant (Cymbopogon citratus) extracted in different solvents for antioxidant and antibacterial activity against human pathogens. Asian Pacific Journal of Tropical Disease. 2014; 4: S134-S139.

10. Moore-Neibel K, Gerber C, Patel J, Friedman M, Ravishankar, S. Antimicrobial activity of lemongrass oil against Salmonella enterica on organic leafy greens. J Appl Microbiol. 2012; 112: 485-492. PubMed: https://pubmed.ncbi.nlm.nih.gov/22188296/

11. Olorunnisola SK, Hammed AM, Simsek S. Biological properties of lemongrass: An overview. International Food Research Journal. 2012; 4: 21.

12. Ghosh K. VAnticancer effect of lemongrass oil and citral on cervical cancer cell lines. Pharmacognosy Communications. 2013; 3: 41.

13. Skaria BP, Joy PP, Mathew S, Mathew G. Lemongrass. In Handbook of herbs and spices. Woodhead Publishing. 2006; 400-419.

14. Elson CE, Underbakke GL, Hanson $\mathrm{P}$, Shrago E, Wainberg RH, et al. Impact of lemongrass oil, an essential oil, on serum cholesterol. Lipids. 1989; 24: 677-679.

PubMed: https://www.ncbi.nlm.nih.gov/pubmed/2586227

15. Schreuder M. U.S. Patent Application No. 13/533,684. 2013.

16. Silva CD. BD, Guterres SS, Weisheimer V, Schapoval EE. Antifungal activity of the lemongrass oil and citral against Candida Braz $\mathrm{J}$ Infect Dis. 2008; 12: 63-66.

PubMed: https://www.ncbi.nlm.nih.gov/pubmed/18553017

17. Oyedele AO, Gbolade AA, Sosan MB, Adewoyin FB, Soyelu OL, et al. Formulation of an effective mosquito-repellent topical product from lemongrass oil. Phytomedicine. 2002; 9: 259-262.

PubMed: https://www.ncbi.nlm.nih.gov/pubmed/12046869

18. Boukhatem MN, Ferhat MA, Kameli A, Saidi F, Kebir HT. Lemon grass (Cymbopogon citratus) essential oil as a potent anti-inflammatory and antifungal drugs. Libyan J Med. 2014; 9: 25431.

PubMed: https://www.ncbi.nlm.nih.gov/pubmed/25242268 
19. Chaisripipat W, Lourith N, Kanlayavattanakul M. Anti-dandruff hair tonic containing lemongrass (Cymbopogon flexuosus) oil. Complementary Medicine Research. 2015; 22: 226-229.

PubMed: https://www.ncbi.nlm.nih.gov/pubmed/26566122

20. Ekpenyong CE, Daniel NE, Antai AB. Bioactive natural constituents from lemongrass tea and erythropoiesis boosting effects: potential use in prevention and treatment of anemia. J Med Food. 2015; 18: 118-127.

21. Rajesvari R, Lakshmi T. Lemon grass oil for improvement of oral health. Dental Hypotheses. 2013; 4: 115.

22. Leite J, Maria De Lourdes VS, Maluf E, Assolant K, Suchecki D, et al. Pharmacology of lemongrass (Cymbopogon citratus Stapf). III. Assessment of eventual toxic, hypnotic and anxiolytic effects on humans. J Ethnopharmacol. 1986; 17: 75-83.

23. Mirghani MES, Liyana Y, Parveen J. Bioactivity analysis of lemongrass (Cymbopogan citratus) essential oil. 2012.

24. Tsui B, Dennehy CE, Tsourounis C. A survey of dietary supplement use during pregnancy at an academic medical center. Ame $\mathrm{J}$ Obstet Gynecol. 2001; 185: 433-437.

PubMed: https://www.ncbi.nlm.nih.gov/pubmed/11518905

25. Carson CF, Hammer KA, Riley TV. Melaleuca alternifolia (tea tree) oil: a review of antimicrobial and other medicinal properties. Clin Microbiol reviews. 2006; 19: 50-62.

PubMed: https://www.ncbi.nlm.nih.gov/pmc/articles/PMC1360273/

26. Drury S. Tea Tree Oil: A medicine kit in a bottle. Random House. 2011

27. Hart PH, Brand C, Carson CF, Riley TV, Prager RH, et al. Terpinen-4$\mathrm{ol}$, the main component of the essential oil of Melaleuca alternifolia (tea tree oil): suppresses inflammatory mediator production by activated human monocytes. Inflamm Res. 2000; 49: 619-626.

PubMed: https://www.ncbi.nlm.nih.gov/pubmed/11131302
28. Carson CF, Riley TV. Antimicrobial activity of the major components of the essential oil of Melaleuca alternifolia. J Appl Bacteriol. 1995; 78: 264-269.

PubMed: https://www.ncbi.nlm.nih.gov/pubmed/7730203

29. Klauck V, Pazinato R, Stefani LM, Santos RC, Vaucher RA, et al Insecticidal and repellent effects of tea tree and andiroba oils on flies associated with livestock. Med Vet Entomol. 2014; 28(S1): 33-39. PubMed: https://www.ncbi.nlm.nih.gov/pubmed/25171605

30. Pasay N, Yaghoobi R, Bagherani N, Kazerouni A. A review of applications of tea tree oil in dermatology. Int J Dermato. 2013; 52 : 784-790.

PubMed: https://www.ncbi.nlm.nih.gov/pubmed/22998411

31. Knight TE, Hausen BM. Melaleuca oil (tea tree oil) dermatitis. J Ame Academy Dermatol. 1994; 30: 423-427.

32. Pazyar N, Yaghoobi R, Bagherani N, Kazerouni A. A review of applications of tea tree oil in dermatology. Int J Dermatol. 2013; 52: 784-790. PubMed: https://www.ncbi.nlm.nih.gov/pubmed/22998411

33. Hammer KA, Carson CF, Riley TV, Nielsen JB. A review of the toxicity of Melaleuca alternifolia (tea tree) oil. Food Chem Toxicol. 2006; 44: 616-625.

PubMed: https://pubmed.ncbi.nlm.nih.gov/16243420/

34. Chin KB, Cordell B. The effect of tea tree oil (Melaleuca alternifolia) on wound healing using a dressing model. J Altern Complemen Med. 2013; 19: 942-945.

PubMed: https://www.ncbi.nlm.nih.gov/pubmed/23848210

35. Potluri A, Shaheda SK, Rallapally N, Durrivel S, Harish G. A review on herbs used in anti-dandruff shampoo and its evaluation parameters. 